\title{
Enhancing Throughput of Optimum Channel in OFDM Based Full Duplex Communication
}

\author{
Saravana.S, Sidharth Raj.R.S, Mohan Raj.R.
}

\begin{abstract}
The efficient use of radio facilities in cellular networks is essential and being widely studied. This letter sees a cellular relay system where various user couples perform trans-directional interaction via various relays relying on Orthogonal Frequency-Division Multiplexing (OFDM) communication.. Joint implementation of route and transmit allocation, along with subcarrier coupling, subcarrier distribution as well as relay choice, for complete output redistribution is identified as a combination estimation issue.. Using a graph conceptual strategy, we can efficiently fix the problem in exponential time by converting it into a Optimum Adjusted Bipartite Tracking (MWBM) issue. Simulation experiments are conducted to assess the complete throughput of the network versus transmitting energy per node and the number of relay nodes. Carrier frequency offset causes a number of impairments including attenuation and rotation of each of the subcarriers and intercarrier interference (ICI) between carrier frequency offset causes a number of impairments including attenuation and rotation of each of the subcarriers and intercarrier interference (ICI) between subcarriers. In the mobile radio environment, the relative movement between transmitter and receiver causes doppler frequency shifts, in addition, the carriers can never be perfectly synchronized. These random frequency errors in OFDM system distort orthogonality between subcarriers and thus intercarrier interference (ICI) occurs. A Number of methods have been developed to reduce this sensitivity to frequency offset

Keywords : OFDM, ICI, Doppler frequency shifts.
\end{abstract}

\section{INTRODUCTION}

Transmitter system generate the different shape of carrier signal. Which can be transmitted over the relay network. Relay network means intermediate network which has been increase carrier signal strength.Relay network used to pair sub-carrier signal these are orthogonality each other to all carrier signal. Relay network also maintain the MAC phase operation. Relay network performed Orthogonal Frequency Division Multiplexing (OFDM) based Full Dupulex Communication(FDC).[1-10]

Full dupulex communication process is used to exchange the carrier signal beween transmitter and receiver at simutanously through the intermediate network. In intermediate network relay node selection is difficult process because which is going to select the shortest path.Sub-carrier pairing of OFDM based full dupulex communication used enhancing the

Revised Manuscript Received on August 22, 2019.

Saravana.S Assistant Professor, Department of Electronics And Communication Engineering,, Bharath Institute of Higher Education and Research, Chennai, India. selvidurai1975@gmail.com.

Sidharth Raj.R.S, Assistant Professor, Department of Electronics And Communication Engineering,, Bharath Institute of Higher Education and Research, Chennai, India. sidarthraj93@gmail.com

Mohan Raj.R, Assistant Professor, Department of Electronics And Communication Engineering,, Bharath Institute of Higher Education and Research, Chennai, India.dspmohanraj@gmail.com. throughput. OFDM based full duplex communication system use double sub-carrier which can be used to decrease packet latency.These system use two kind of relay network one is transmitter side relay network and another one is receiver side relay network. Both transmitter side relay network and receiver side relay network are uses paired sub-carrier.[11-15]

\section{II.METHODOLOGY}

\section{A. Subcarrier Pairing}

Basic functional block diagram of subcarrier pairing Orthogonal Frequency division multiplexing based full dupulex communication network system is shown in the figure 4.3. The relay network have two types of amplification phases one is MAC phase and another one is BC phase.These two phases are used to increase the strength of the signal. Figure 4.3 there are two subcarrier one can be denoted as subcarrier1 and another one can be denoted as subcarrier2.Both can be paired equally and form as single and carrier pairing process is orthogonal to each other[16-20]

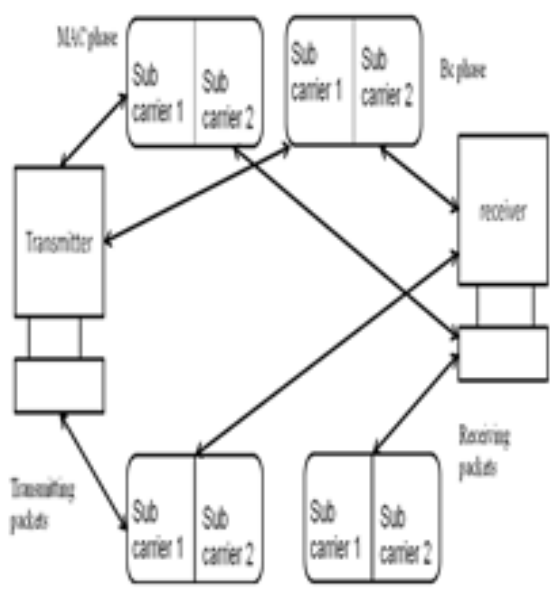

Fig 1. Block Diagram Of OFDM Based Full Dupulex Communication

Transmitting packets occupay subcarrier1 and receiving packets locate on receiving packets. So both transmitting operation and receiving operation has been happening simultaneously which can be called as Orthogonal Frequency Division Multiplexing based full dupulex communication 


\section{Enhancing Throughput of Optimum Channel in Ofdm Based Full Duplex Communication}

\section{III.RESULT}

Carrier signal can be generate from the transmitter and these carrier signal choice the relay node. This process is called as relay selection. Transmitter generated carrier signal and relay node selection is simulated using MATLAB coding.

Orthogonal Frquency Division Multiplexing transmitter has generated five types of carrier signal. These five carrier signals have to select the relay node on the transmitter side. Transmitter carrier signal reach the relay node of 1, 2, 3, 4, 5 and so these five nodes are called as transmitter side relay node. After that it will reach relay node of $6,7,8,9,10$, which is in receiver side and so these five relay nodes are called as receiver side relay node. Here transmitter generated carrier signal has different shapes. If there is any change in the carrier signal shape means we have to give some modification in MATLAB coding.

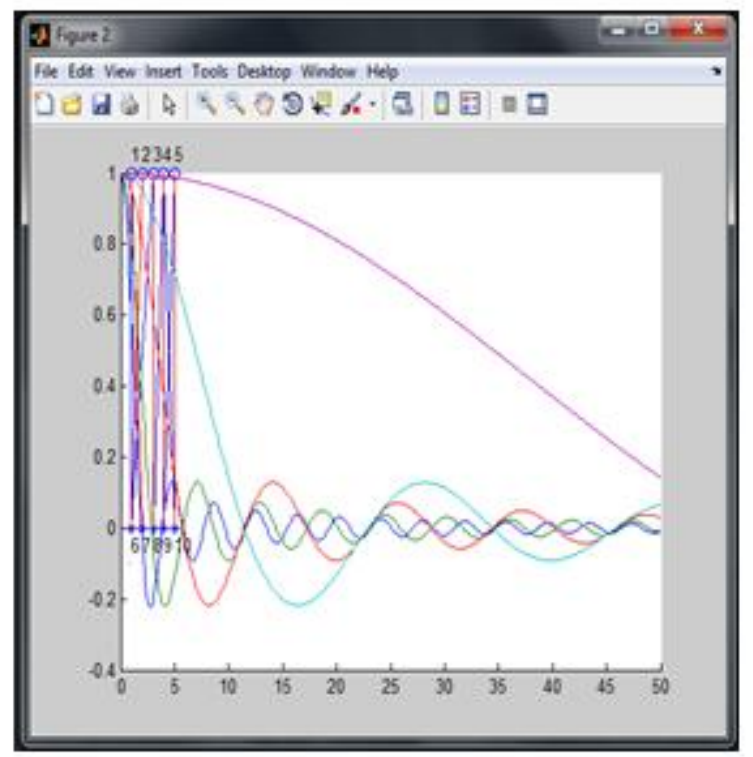

\section{Fig. 2 Simulation For OFDM Transmitter Generated} Carrier Signal

Relay selection simulation figure is shown in the figure 5.2. In this figure we have two types of lines one is blue line and another one is red line. Blue line represents transmitting process and red line represents receiving process. From node 1 send blue line to receiver side relay node of node 6 , node 8 , and node 9 which represent that there is a connection establishment between them. After established, the connection message can be exchanged easily from transmitter to receiver. At the same time there is a red line between relay node 7 and relay node 1 which can exchange the message from receiver to transmitter. From these operation transmitter and receiver exchange the message simultaneously which is called as OFDM based full duplex communication.

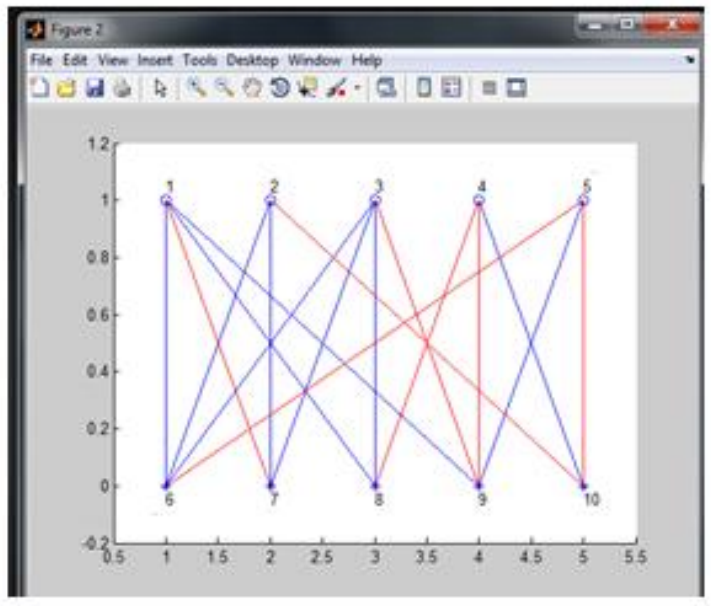

Fig 3. Simulation of relay network node selection

\section{IV.CONCLUSION}

In this work we generated the signal by using transmitter And choice of relays for inter-relay inter-pair full duplex Orthogonal frequency division multiplexing networks. By investigating these latency in full duplex OFDM networks is less compared with half duplex OFDM networks. OFDM transmitted signal maintain power allocation and relay relay node selection control the Broad Cast (BC). BC phase provide Inter Symbol Interference (ISI) avoidance to the OFDM based full duplex communication networks.

In future Work Joint development of comb filter-pairing comb filter allocation will be investigate and maximum bipartiate matching approach is used to share the data at a time between transmitter and receiver. Sub carrier pairing means one signal orthogonally paired with another signal. Here one signal used to carry the transmission signal and another signal used to carry reception signal. These can provide transmitter and receiver exchange the data simultaneously which is used to reduce latency between transmitter and receiver.

\section{REFERENCES}

1. Kongkham, D. \& Sundararajan, M. 2019, "Distributed wideband sensing method for faded dynamic spectrum access", International Journal of Innovative Technology and Exploring Engineering, vol. 8, no. 10, pp. 4309-4312.

2. Balaji, S., John Paul Praveen, A. \& Mohanraj, R. 2019, "Recognizable proof and analysis of palm print in biometric authentication system using bayes techniques", International Journal of Innovative Technology and Exploring Engineering, vol. 8, no. 9 Special Issue 3, pp. 1126-1129.

3. Kavitha, G., Priya, N., Velvizhi, R. \& Allin Geo, A.V. 2019, "Parallel computation in correspondence and signal processing", International Journal of Innovative Technology and Exploring Engineering, vol. 8, no. 9 Special Issue 3, pp. 1136-1139.

4. Hema, R., Sundararajan, M. \& Balaji, S. 2019, "Smartphone control robot with automatic firing gun", International Journal of Innovative Technology and Exploring Engineering, vol. 8, no. 9 Special Issue 3, pp. 625-627.

5. Kaliyamurthie, K.P., Sundar Raj, B., Velvizhi, R. \& Shanmugapriya, K. 2019, "Dual band paper substrate CPW antenna for wireless applications", International Journal of Innovative Technology and Exploring Engineering, vol. 8, no. 9 Special Issue 3, pp. 605-608.

6. Geo, A.V.A., Arunachalam, A.R., Michael, G. \& Elankavi, R. 2019, "Evaluating architecture using compact 
modalities", International Journal of Innovative Technology and Exploring Engineering, vol. 8, no. 9 Special Issue 3, pp. 836-838.

7. Theivasigamani, S., Jeyapriya, D. \& Anita Davamani, K. 2019, "Anamoly analyzing and exploring for wireless sensor networks", International Journal of Innovative Technology and Exploring Engineering, vol. 8, no. 9 Special Issue 3, pp. 1116-1118.

8. Jeyapriya, D., Theivasigamani, S., Velvizhi, R. \& Nandhini, P. 2019 , "Program detection in wireless feeler networks", International Journal of Innovative Technology and Exploring Engineering, vol. 8, no. 9 Special Issue 3, pp. 1194-1195.

9. Gowri Sankaran, B., Karthik, B. \& Vijayaragavan, S.P. 2019, "Image compression utilizing wavelet transform", International Journal of Innovative Technology and Exploring Engineering, vol. 8, no. 10, pp. 4305-4308.

10. Gowri Sankaran, B., Karthik, B. \& Vijayaragavan, S.P. 2019, "Weight ward change region plummeting change for square based image huffman coding", International Journal of Innovative Technology and Exploring Engineering, vol. 8, no. 10, pp. 4313-4316.

11. Hema, R., Sundararajan, M. \& Balaji, S. 2019, "Smartphone control robot with automatic firing gun", International Journal of Innovative Technology and Exploring Engineering, vol. 8, no. 9 Special Issue 3, pp. 625-627.

12. Rangaswamy, K. \& Rajabhushanam, C. 2019, "Congestion control in wireless network using TCP friendly rate control (TFRC)", International Journal of Recent Technology and Engineering, vol. 8 , no. 2 Special issue 3, pp. 1598-1602.

13. Tamil Selvan, S. \& Sundararajan, M. 2019, "Performance Parameters of 3 Value 8t Cntfet Based Sram Cell Design Using H-Spice", International Journal of Recent Technology and Engineering, vol. 8, no. 2 Special issue 5, pp. 22-27.

14. Vinoth, V.V. \& Kanniga, E. 2019, "Steganographical techniques in hiding text images - system", International Journal of Recent Technology and Engineering, vol. 8, no. 2, pp. 6535-6537.

15. Saravana, S., Balaji, S., Arulselvi, S. \& John Paul Praveen, A. 2019, "Reliable power quality monitoring and protection system", International Journal of Innovative Technology and Exploring Engineering, vol. 8, no. 9 Special Issue 3, pp. 644-645.

16. Sundaramoorthy, A. \& John Wiselin, M.C. 2019, "Single patch antenna with multiple feed", International Journal of Innovative Technology and Exploring Engineering, vol. 8, no. 9, pp. 1743-1747.

17. Velavan, R., Bharanidharan, S. \& Sheeba, B. 2019, "EMF pollution Causes, effects and protection", International Journal of Innovative Technology and Exploring Engineering, vol. 8, no. 9 Special Issue 3, pp. 1166-1168.

18. Veer, R.A., Arulselvi, S. \& Karthik, B. 2019, "Construction of ensemble square classification approaches in MIMO OFDM", International Journal of Engineering and Advanced Technology, vol. 8, no. 5, pp. 2039-2041.

19. Agitha, W. \& Kaliyamurthie, K.P. 2019, "Improved energy efficient in WBAN using MAC with cloud computing", International Journal of Innovative Technology and Exploring Engineering, vol. 8, no. 8, pp. 2405-2408.

20. Kastro, G.G. \& Wiselin, M.C.J. 2019, "Design and analysis of stub loaded resonator", International Journal of Recent Technology and Engineering, vol. 8, no. 1 Special Issue4, pp. 272-283.

\section{AUTHORS PROFILE}

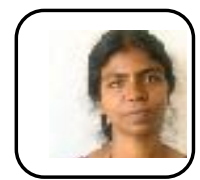

Saravana.S Assistant Professor, Department of Electronics And Communication Engineering,, Bharath Institute of Higher Education and Research, Chennai, India..

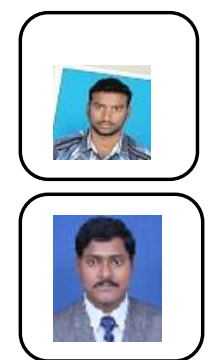

Sidharth Raj.R.S, Assistant Professor, Department of Electronics And Communication Engineering,, Bharath Institute of Higher Education and Research, Chennai, India..

Mohan Raj.R, Assistant Professor, Department of Electronics And Communication Engineering,, Bharath Institute of Higher Education and Research, Chennai, India . 